\section{Career anchors and values from different career management perspectives}

\author{
Rodrigo Cunha da Silva \\ Anhembi Morumbi University, Departament of Business \\ Administration, Sao Paulo, SP, Brazil \\ Leonardo Nelmi Trevisan \\ Pontifical Catholic University of São Paulo, Faculty of Economics, \\ Business Administration, Accounting and Actuarial, Department \\ of Economics, Sao Paulo, SP, Brazil
}

Elza Fátima Rosa Veloso

United Metropolitan Colleges, Graduate Studies

Program in Business Administration, Sao Paulo, SP, Brazil

\section{Joel Souza Dutra}

University of Sao Paulo, Faculty of Economics, Business Administration and Accounting, Department of Business Administration, Sao Paulo, SP, Brazil

\begin{abstract}
Purpose - To analyze the relationships between career anchors and young Generation Y professionals' values, from the career concept perspective.
\end{abstract}

Design/methodology/approach - Research concerning the proposed objective was carried out through quantitative research involving 189 Business Administration majors from a Catholic university in São Paulo, Brazil. We used two instruments to identify the career anchors and values of respondents: Schein (1990) and Schwartz (1994), respectively. We used statistical techniques to explore the relationships between career anchors and values.

Findings - Among the results, mention should be made to the statistical relationships found between analyzed career anchors and values. It is also important to stress that, although the Lifestyle career anchor was predominantly present in the conglomerate division, this anchor was the predominant characteristic in the differentiation of the smaller group of respondents, the new career group. The General Management Career Anchor, which presents a lower incidence, is the predominant characteristic of the larger group, referring to organizational careers. As well as the Lifestyle career anchor, the Hedonism value was predominant among respondents.

Originality/value - The need to consider the following was found: Generation Y presents generational characteristics that drive people management to propose work structures that offer activities to generate learning, pleasure, self-fulfillment and conciliation between work and personal life.

Keywords - Career anchors; values; career management
Received on

Nov./19/2014

Approved on

Apr./29/2016

Responsible editor:

Prof. Dr. João Maurício Gama

Boaventura

Evaluation process:

Double Blind Review

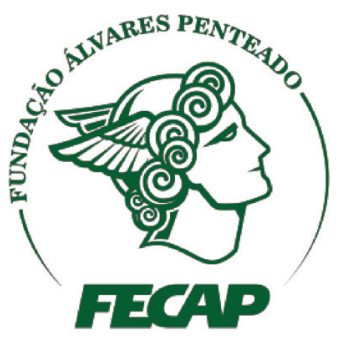

Review of Business Management

DOI: $10.7819 /$ rbgn.v18i59.2260 


\section{Introduction}

Young professionals from the beginning of this century are generally referred to as Generation Y, or are called Millenniums; in Brazil, this generation is made up of people born from 1986 onwards (Silva, Dutra, Veloso, Fischer, \& Trevisan, 2015). This generation tends to be restless, and is challenging and even insubordinate with regard to different aspects of everyday life within organizations.

Learning about generations' values is useful, both in a personal as well as in an organizational context. Several studies sought to verify the generational differences in terms of their work values (Cennamo \& Gardner, 2008; Smola \& Sutton, 2002; Twenge, Campbell, Hoffman \& Lance, 2010). According to Westerman and Yamamura (2007), companies should acknowledge the influence of values in the preferences of generations with regard to work, as well as their relationship with organizational performance, whether seeking to retain these professionals or to develop their future leaders.

In a general context, some other studies showed the importance of learning, career growth perspectives and work-life balance to Generation Y commitment (Costanza, Badger, Fraser, Severt, \& Gade, 2012; D’Amato \& Herzfeldt, 2008). Other analyses showed that Generation Y's organizational commitment could be rooted in the fulfillment of social recognition, lifestyle and pleasure expectations (Lyons \& Kuron, 2014; Twenge et al., 2010).

In Brazil, there is evidence of age-based generational differences among professionals, particularly in the way they conduct their careers within organizations. (Veloso, 2012b; Veloso, Silva, \& Dutra, 2012). Although there has been progress in studies about generations in Brazil and in other countries, the findings are not conclusive; this shows that there is scope for further research into the subject. Still, it is possible to confirm the influence of aspects of interpersonal relationships that create emotional bonds which, in turn, should be considered in the management of generations within the work environment. Veloso et al. (2012) reinforce this statement when confirming the negative impact that the relationship network has on this generation's perspective of professional growth, in a Brazilian context. These authors have also verified that, through the eyes of Generation $\mathrm{Y}$, interpersonal relationships within Brazilian organizations are extensions of personal life and do not determine professional growth.

In addition, it is important to remember, according to Silva et al. (2015), that other generations have characteristics that differ from Generation Y's. The Baby Boom Generation (born between 1946 and 1964), for example, is made up of people who believe in having one single job throughout their working lives, and who are loyal to the organization they work for; generation $\mathrm{X}$ people (born between 1965 and 1985), on the other hand, are skeptical, doubtful and not as committed to the organization they work for as Baby Boomers.

In order to understand Generation $Y$, it is crucial to consider a fact that has been broadly emphasized in a social and conceptual from the 1990s on: the way we see careers is constantly changing since the 1990s. Career views depending on employers were replaced by formats managed more by individuals than by the organization itself. In this view of "new careers", values are more and more determinant to professional choices (Arthur, Inkson \& Pringle, 1999; Veloso, 2012a). Furthermore, it is important to consider the importance of career anchors in the analysis of Generation Y's professional career paths. Originally, career anchors were conceived by Edgar Schein (1990) to discover the values that determine professional motivation and inclinations. Currently, this concept has been very useful in numerous studies about professional choices among young adults; for example, in the analysis of the relationship between stress and technology (Trevisan, Veloso, Silva, \& Dutra, 2015); in the analysis of economic variations (Veloso, Silva, Trevisan, Gomes \& Dutra, 2014); or in understanding professional mobility (Gomes, Moraes, Barbosa, \& Trevisan, 2013). 
This study aims to analyze the relationships between career anchors and the values of young Generation Y professionals, from the perspective of career concepts. The reason to study this objective is in the fact that these anchors essentially encompass personal values that define professional inclinations. Although the isolated analysis of anchors limits possibilities of investigating important career issues, when associated with other levels they can potentially generate a deep understanding about the professional choices of specific groups such as Generation Y.

In the relationship proposed in this article, considerations which admit not having enough knowledge about the involvement of personal values with career anchors have been taken into account. Santos and Abrahim (2008) emphasized the need for further research on the study of the relationship between these two concepts, due to a gap in literature that deals with professional inclinations, which are motivated not only by values, but also by other factors such as talent, market pressures and opportunities.

The study of the proposed objective was carried out through quantitative research involving Business Administration majors from a Catholic university in São Paulo, Brazil, and its hypotheses and key concepts will be presented in the next section. The following sections of this article present the research methodology, the analysis and discussion of findings and, lastly, the contributions of this study.

\section{Theoretical reference and research hypotheses}

\section{I Career management}

To some researchers, such as Bendassoli (2009), the term career can mean wage employment, although many other meanings can be considered. The author mentions, for example, the sense of belonging to a professional group; vocation (something someone does with a high level of emotional involvement); and occupation (something someone does by necessity or obligation). The word can also be used to designate an employee's ranking within the organization (associated with numerous role transitions within the hierarchy), to refer to an entrepreneur's career path or, even, to a personal roadmap to fulfill one's own wishes. Dutra (2010) highlights career as occupational mobility, a road ahead, or as occupational stability, which represents the career as a profession.

In Hall's (2002) understanding, career is the individual perception on the sequence of attitudes and behaviors associated with work and task experiences throughout life. In this author's perspective, career is not necessarily a linear succession of experiences and projects, a belief predominant up to the 80 s, when the professional individual sought to work in one single company throughout his whole life. According to this understanding, seniority and maturity were valued and respected qualities. Furthermore, a stable environment was presumed, where learning occurred exclusively within the organization. Despite the progress in the concept pointed out by Hall, some of the characteristics in traditional careers still influence professional choices (Briscoe, Hall, \& DeMuth, 2006), such as, for example, the search for recognition and status or the desire to move up within the organizational hierarchy (Silva, Dias, Krakauer, Silva, \& Marinho, 2012).

In the last two decades, however, another phenomenon associated with careers gained strength in developing countries: the emergence of initiatives to fight social and environmental issues. From the 1990s, a growth in corporate social responsibility actions was observed, as well as the intensification of performance in civil society organizations (Moura, Comini \& Teodósio, 2015). With this trend, the desire for a career in social businesses has grown among many Generation Y young administrators (Rosolen, 2014).

As well as a personal perspective - broadly emphasized from the 1990s - the perspective of company management also became essential in career management analysis (Dutra, 2002). The assimilation of these conceptual developments is 
important to organizations, since the possibility of a career path in a company is still a relevant motivation factor for workers. For this reason, it is interesting for the company to organize itself so as to offer development spaces to its employees. The clarity regarding moving perspectives within the company structure provides employees with a better understanding about their professional possibilities. In other words, knowing the criteria regarding access to specific levels allows the individual to channel efforts towards his/her own development (Veloso et al., 2011).

From the 1990s on, after overcoming the traditional career view, the intelligent company was then "capable of destroying hierarchy, breaking away from organization chart levels, outsourcing what is not within its main competency and concentrating on what it does best" (Arthur, Claman, \& DeFillippi, 1995, p. 7). According to these authors, intelligent companies had three distinct competences: a culture capable of absorbing employee contribution (knowwhy); technical knowledge (know-how); and a relationship network giving access to external resources (know-whom). Therefore, professionals and organizations would start to develop these competences in a shared manner.

\subsection{The new careers}

At the end of the 20th century and the beginning of the 21 st century, researchers started to detect two important movements of professionals with regard to careers: those who, like the Greek god Proteus, acquire the ability to adapt to constant changes; and those who look beyond organization boundaries, either in search of learning, or in network development. These movements have been called, respectively, "protean career" and "boundaryless career". Theoretically, both are contrary to the organizational career model (Sullivan \& Baruch, 2009), as shown in Table 1.

\section{Table 1}

\section{Career model comparison}

\begin{tabular}{|c|c|c|}
\hline Types of careers & Theoretical background & Attitudes \\
\hline Protean career & $\begin{array}{l}\text { Protean career is the career managed more by the person than } \\
\text { by the organization. It involves independence from external } \\
\text { influences. Self-management and inner success (psychological) } \\
\text { are two variables. It is shaped more by individuals than by the } \\
\text { company and can be redirected periodically to fulfill the needs } \\
\text { of the individual, who must have a proactive personality. }\end{array}$ & $\begin{array}{l}\text { (1) The individual takes control over his/her own } \\
\text { career instead of delegating it to the organization, } \\
\text { creating his/her own opportunities. } \\
\text { (2) The person gives priority to his/her own values } \\
\text { when establishing priorities and objectives. The } \\
\text { definition of success is based on personal criteria. }\end{array}$ \\
\hline Boundaryless career & $\begin{array}{l}\text { The person is responsible for his/her own career, which happens } \\
\text { with the production of networks and the constant search for } \\
\text { access to knowledge and to external resources. Careers move } \\
\text { through the employer's boundaries; the hierarchical discourse } \\
\text { and the principles of progress have their boundaries broken; } \\
\text { career decisions are based on personal reasons; a boundaryless } \\
\text { future is perceived; personality must be proactive. There are } \\
\text { two types of mobility: physical and psychological. }\end{array}$ & $\begin{array}{l}\text { (1) There is a preference for interacting with } \\
\text { people and organizations beyond the company's } \\
\text { boundaries. } \\
\text { (2) There is the desire to work for many companies } \\
\text { throughout the career. (3) Commitment occurs in } \\
\text { exchange for development opportunities. } \\
\text { (4) The person seeks to learn inside and outside } \\
\text { the company with a proactive attitude. }\end{array}$ \\
\hline Organizational career & $\begin{array}{l}\text { Predominant up to the } 1980 \text { s. The person works for a } \\
\text { company until retirement. Seniority and maturity are socially } \\
\text { valued and respected. Careers are linked to large organizations; } \\
\text { they expect a stable environment; there is interdependency } \\
\text { between company and individual; learning takes place within } \\
\text { the organization; knowledge transfer is carried out only within } \\
\text { the company. }\end{array}$ & $\begin{array}{l}\text { (1) The person plans to stay in the same company } \\
\text { for life. Changes cause apprehension and uneasiness. } \\
\text { (2) Professional development is determined by } \\
\text { company interests; } \\
\text { (3) Career changes are made only to meet company } \\
\text { requirements. } \\
\text { (3) The desire to climb is hierarchical, since it leads } \\
\text { to the achievement of symbols of power and status. }\end{array}$ \\
\hline
\end{tabular}

Note: Adapted from "The boundaryless career: A new employment principle for a new organizational era," by M. B. Arthur and D. Rousseau, 1996; "The new careers: Individual action and economic change," by M. B. Arthur, K. Inkson and J. K. Pringle, 1999; "The "new career" and organizational commitment - do boundaryless and protean attitudes make a difference?," by J. P. Briscoe and L. M Finkelstein, 2009, Career Development International, 14, p. 242-260; and "Career management,", by J. S. Dutra, 2002. 
Looking at Table 1 , it is possible to note that the organizational career model is based on the notion of employment inherited from the industrial society, according to Bendassoli (2009). Within this view, the employee makes an exchange with the organization: while the person devotes himself/herself and is loyal to the company, he/ she receives, as a reward, security and stability. The security factor, however, has been changing. Currently, it is more related to the individual's personal qualifications and attitudes rather than to his/her devotion to a single employer (Veloso $\&$ Dutra, 2010).

In the last decades, the decline of the organizational career has been followed by the rise of "new careers": the protean career and the boundaryless career (Arthur et al., 1999). "Protean attitudes" are positively related to proactive personalities, career authenticity, openness to experiences and orientation by objectives. Among those classified within protean careers, characteristics such as greater mobility and orientation by learning are identified; however, these characteristics are not preconditions for the protean career. Self-management, for example, is present in people oriented more by objectives and personal growth, and less by job security. "Orientation by values" leads the individual to measure success based on his/her own values (psychological success), and not on external opinions (Briscoe, Hall, \& DeMuth, 2006).

Research on boundaryless careers, on the other hand, has addressed attitudes that define them (Briscoe, Hall, \& DeMuth, 2006; Veloso, 2012a). According to this new definition, the professional with a boundaryless career attitude is independent as to the traditional settings of the organizational career, seeking opportunities that go beyond a single employer (Arthur \& Rousseau, 1996). There is a consensus that this type of professional feels comfortable either with physical movements, which involve job and company changes, or with psychological ones, which involve the creation and support of active relationships beyond the company's boundaries (Briscoe, Hall, \& DeMuth, 2006).
In spite of the mobility proposed by new careers, Dutra (2010, p. 65) states that "people tend to remain in professional activities of the same nature," which the author calls "career path". If the person remains in the same path, he/she develops faster. However, in case he/she changes path, he/ she will have to deal with other complexities, among them the change in professional identity. To explain how painful and hard this process is, the author uses the expression "skin change" as a metaphor for this identity change.

Briscoe and Finkelstein (2009) found that protean careers and boundaryless careers do not show a negative relation to organizational commitment, except for the professionals' preference for organizational mobility. In parallel, the current career concept is focused on the individual's subjective and objective experience, on the way he/she builds his/her career, on the relationships established with each task, associated both to his/her personal and professional lives (Clarke, 2013). According to this author, this "new organizational career" does not imply the rupture between organizational careers and new careers, but it means that new career management models comprise both new and traditional attitudes from professionals.

Considering the advances in career concepts, as well as Clarke's observations, the first hypothesis of this study is as follows: Hypothesis 1 - Generation $Y$ respondents are oriented both to organizational careers and to new careers.

\subsection{Career anchors}

The "career anchor" concept has its origin in the study by Schein (1990), which was carried out with the purpose of gathering knowledge on the construction of values that follow an individual throughout his/her professional activity. In his research, Schein carried out interviews with students in the Masters Program at the Massachusetts Institute of Technology (MIT) Sloan School of Management, and also after they concluded the course, at their workplaces. During this period of studies changes in careers were critically observed, as well as their respective reasons and/or attributions, values and attitudes. 
From the analyses, it was possible to extract conclusions related to internal career evolution and the metaphorical concept of "career anchor", which suggests that the professional individual - when in a situation of imbalance with his/her values, attitudes and objectives - tends to return to a comfortable situation with his/her self-image. According to the researcher's report (Schein, 1990), individuals who were trying other jobs rather than those they were adapted to, frequently referred to the image of returning to those activities they were more and better adjusted to. To him, the individual's professional inclination (reference point) is so important that, as well as not being discarded - even in crisis situations - it is what defines his/her self-image according to the predominant area in his/her career. General characteristics of each type of professional inclination, which consists in a set of self-perceptions referring to talents, abilities and attitudes based on real individual experiences, are portrayed below, in the description of career anchors.

a) Technical/Functional (TF) Competency - In this anchor, the professional acquires a sense of identity through the application of his/her technical abilities, and professional achievement comes from the possibility of facing challenges in this area;

b) General Management (GM) Competency - Relates to the professional who is motivated by the opportunity to lead, take decisions and establish impact guidelines in organizations. The person seeks to achieve career success by securing a high position in the organizational hierarchy and power to influence others;

c) Autonomy/Independence (AI) - This group includes people who have a reduced level of tolerance towards rules established by other people, by procedures and other types of control that may limit his/her autonomy;

d) Security/Stability (SS) - In this anchor, the main worry is the feeling of well-being created by low career instability. To this end, the professional anchored here will guide his/her decisions based on security and stability;

e) Entrepreneurial Creativity (EC) - This group includes professionals focused on creating new organizations, services or products;

f) Service/Dedication to one Cause (SD) In this anchor there is no resignation, under any hypothesis, from tasks that are consistent with the individual's personal values;

g) Pure Challenge (PC) - The incessant search for overcoming apparently impossible obstacles and the solution of insoluble problems define success for the professionals anchored in this group;

h) Lifestyle (LS) - In this anchor, the professional seeks to find a way of integrating individual and family needs with career demands.

As individuals perceive themselves and get conscious about their own professional preferences, they become more apt to make conscious choices. Still on the career anchor concept, Dutra (2010, p. 7) highlights its importance because "it influences choices, affects decisions for a task/ job change to another, determines visions of the future, influences the choice of specific occupations and affects individuals' reactions towards work". The importance of career anchors is notorious; however, the assimilation of concept changes determined by economic issues can influence the incidence of anchors in certain periods (Veloso et al., 2014). Based on this view, the second hypothesis of this study is as follows: Hypothesis 2 - There are differences between the anchors of young Generation $Y$ adults oriented towards an organizational career and those oriented towards new careers.

\subsection{Careers and values}

As companies seek to manage careers, considering actual and potential employee values becomes important, for people and organizations alike. Fewer professionals choose to build their career path in a single organization, either by 
personal desire or by the need of companies to renew their staff and keep small workforces. Since job stability is no longer guaranteed, organizations seek to align individual preferences and values to their organizational values, aiming at a committed relationship (Silva, Trevisan, Veloso, \& Dutra, 2014).

From the organizational perspective, Hofstede (1997) evaluates cultural values in relation to five dimensions: individualism versus collectivism; distance from power; avoiding uncertainty; masculine versus feminine; and longterm orientation. Based on these variables, Caldas (2006) describes Brazilian culture as having tendencies of keeping a distance from power, having a medium to high level of collectivism, being more feminine than masculine and preference for avoiding uncertainties.

In the case of personal values, according to Robbins, Judge and Sobral (2010, p. 138), these are characterized by basic convictions that "a specific form of conduct or condition of existence is individually or socially preferable to the opposite or adverse manner of conduct or existence". These differences are more evident when analyzed from the cultural value aspects of a nation. Generally, values have, inherently, an element of judgment based on what the individual believes to be correct, good or desirable. According to these authors:

Values have both content and intensity
attributes. The content attribute
determines that a form of conduct or
condition of existence is important.
The intensity attribute specifies how
important it is [...]. Furthermore,
values are generally stable and long
lasting. Values establish the basis for
understanding attitudes and motivation,
as well as influencing our perceptions.
(Robbins et al., 2010, p. 138).

As to value content, Rokeach (1979) proposed two sets, terminal values and instrumental values. The so-called terminal values relate to desirable conditions of existence or, in other words, life objectives and targets. Instrumental values, on the other hand, represent the means to achieve terminal values.

With regard to the intensity and direction of values, Schwartz (1994, 2005) developed the structure of human values, divided in ten motivational types: (a) Selfdetermination (independent thinking and action); (b) Stimulation (excitement, novelty, life challenge); (c) Hedonism (pleasure and sense of self-gratification); (d) Achievement (personal success through a demonstration of competency); (e) Power (social status and prestige, control over people and resources); (f) Security (harmony and stability in society, relationships and with oneself); (g) Conformity (restriction of actions or impulses that tend to damage others or violate social norms); (h) Tradition (respect, commitment with habits and ideas provided by culture or religion); (i) Benevolence (preserving and strengthening the wellbeing of the closest group); (j) Universalism (understanding, gratitude and protecting the wellbeing of all people and nature).

These ten motivational types were grouped in two bipolar value dimensions. On one side there is Self-transcendence (Universalism and Benevolence), which is opposed to Self-promotion (Power, Achievement, Hedonism); on the other side there is Openness to change (Hedonism, Stimulation and Self-determination), opposed to Conservatism (Tradition, Conformity and Security). It is worth stressing that the Hedonism motivational type is related, at the same time, with Openness to change and with Self-promotion (Schwartz, 1994).

Pereira (2016) presupposes that values rule behaviors associated with professional activity which, when identified, benefit individuals and organizations alike. In parallel, it is important to consider the following fact, emphasized by Arthur et al. (1999): in new careers people tend to guide themselves by their values in order to make professional choices. Considering these reflections, the third hypothesis of this study is as follows: Hypothesis 3 - There are differences between the values of Generation $Y$ young adults oriented towards organizational careers and those oriented towards new careers. 


\subsection{Relationship between anchors and values in the view on generations}

Contextual factors may interfere in both anchors and values. In parallel, Elder (1998) reveals how significant historical and social events and experiences can be to the point of shaping the behavior of individuals throughout their lives. Historical forces shape people's social paths with their families, education and work, influencing their behaviors and development. Therefore, anyone is capable of selecting the paths he wants to follow, but these choices do not occur in a social vacuum. They depend on opportunities and restrictions in the individual's social and cultural structure. Both in career anchors (Kilimnik, Sant'anna, Oliveira, \& Barros, 2008), and in Schwartz's model of values (Reis, Antonio, Laizo, \& Marinho, 2010), hierarchies are predicted to change throughout time. Therefore, both views support the understanding about different situations associated with career choices (Pereira, 2016).

As to generations, Howe and Strauss (2007) add that they are not defined only by events that influence people in their early years of development, but also that they are still being shaped as they grow old. In this sense, Smola and Sutton (2002) stress that the influence of age, resulting from the individual's maturation process, cannot be mistaken by the influence of the generation to which the individual belongs.

In the relationship between values and career anchors, Ibarra (2009) addresses the criteria levels for the individuals' decisions, implicit in professional path changes. In this author's view, the first level - the most visible - is on employment and work sector; on the second level are values and motivation factors, preferred space of career anchors; and, on the third level, is the individual's mental map, his own view of the world, essential to define his/her behavior. Based on Ibarra's view, which places anchors and values in the same level of career decisions and, since value groups of Generation Y individuals are important to this research, the fourth hypothesis in this study is as follows: Hypothesis 4 - There is a relationship between career anchors and values in Generation $Y$ professionals.

\section{Methodology}

In this section describes the methodological procedures adopted in the research. Generally, in order to fulfill the main objective of this study, results from a descriptive research were used, which has, among its purposes, the collection of opinions, attitudes and beliefs of a population (Gil, 1999).

The survey was carried out through the application of quantitative questionnaires with 189 respondents. Subjects investigated were students from the 2013 Business Administration course of a Catholic university in São Paulo, Brazil. It is important to highlight that the Business Administration course at this institution is oriented by a humanistic and ethical vocation and although the majority are paying students, the course also holds students who have been awarded a scholarship or who have received a social program benefit. The steps defined for the approach of respondents and for the analysis planning, described below, were based on the checklist by Bido, Souza, Silva, Godoy and Torres (2010), especially with regards to the specification of instruments, collection, evaluation and preparation of data.

Two instruments were used to identify career anchors and values of individuals - Schein (1990) for career anchors and Schwartz (1994) for values. The approach of students and the collection of data followed an application schedule previously agreed with teachers from the Business Administration course, who taught daytime and evening graduate classes. As a result, all classes were included in the sample. Once meeting dates and times were defined, researchers visited the classrooms and applied the questionnaires, thus ensuring the biggest possible number of respondents. The first questionnaire was about career anchors and, followed by the values questionnaire. This is, therefore, a cross-sectional data collection. 
As to the rating scales, it is important to stress that the career anchors questionnaire had 40 questions, allowing the attribution of a grade from 1 to 6 for each anchor. The values questionnaire, on the other hand, had summarized descriptions for each set of 10 motivational types, distributed across 57 items, also with a scale from 1 to 6 .

The software used to analyze and process the data was SPSS, version 22. Multicollinearity and linearity were verified among the variables, with Pearson's bivariate correlations calculation, to evaluate the correlation matrix of variables selected to get into the Analysis of Variance (ANOVA). The strength of correlations was classified as follows: from 0.00 to 0.30 they are non-correlated; between 0.31 and 0.50 they are weakly correlated; between 0.51 and 0.70 they are moderately correlated; between 0.71 and 0.90 they are strongly correlated; from 0.91 to 1.00 they are excessively correlated. In this study, assertiveness questions had correlations between 0.51 and 0.70 , being moderately correlated. Furthermore, the Kolmogorov-Smirnov test was applied, which has a null hypothesis that the variable distribution is normal, a fact confirmed in the variables analyzed.

The assertiveness questions with an omitted data frequency above 5\% were analyzed with regards to their systematic nature. From then onwards, a decision was made to exclude omitted cases from further analyses due to the randomness of omissions. Extreme multi varied cases were verified by the Mahalanobis distance and were identified by presenting values above the critical value of $\chi^{2}$ with significance at $0.01 \%$. Finally, Cronbach's Alpha reliability index was calculated, which in all constructs, for assertiveness questions both in career anchors and in values, presented levels above 0.7. Therefore, the preliminary analysis values were satisfactory in two scales; partly, for being instruments broadly validated over the years in different countries, including versions already translated into Brazilian Portuguese.

In order to analyze the relationships between career choice orientations and values of young Generation Y professionals, the Analysis of Variance (ANOVA) was carried out, offering more flexibility in the test for group differences, since it provides the researcher with the possibility of testing differences in more than two groups (Hair, Black, Babin, Anderson, \& Tatham, 2009). In this case, planned comparisons or post hoc tests were employed. The Scheffé method was used for being the most conservative in relation to Type 1 error, that is, to conclude that two averages are significantly different, when in reality they are the same (Hair et al., 2009). Such analysis allowed comparisons of career anchors and values to be carried out. A value variation analysis was also carried out, focusing on the respondents' main career anchor.

Then, since the purpose of the work was to consider the perspective of career concepts, two groups were defined a priori, from the analysis of the literature presented in the theoretical framework. To that end, a multivariate statistical analysis of conglomerates was carried out, specified as follows: Organizational Career (careers managed more by the company than by the individual); and New Careers (careers managed more by the individual than by the company). In this analysis, the $K$-means method was adopted, considering the averages in respondents' career anchors and values.

\section{Analysis and discussion of results}

In this section, results are analyzed and interpreted, starting with the assessment of career anchors and values. Next, evaluation of the impact of the main career anchor on respondents' values is carried out. Finally, the relationships between anchors and values is identified, aiming at exploring respondents' career perspectives.

The average age of respondents was 23 with a standard deviation of 1.68. The oldest age was 28 and the youngest 19. Therefore, in 2013, the year the research was carried out, the oldest respondent had been born in 1986, within Generation Y traditional age group, according to Silva et al. (2015). From the total, 50\% of subjects researched were men and 50\% were women. 


\section{I Career anchors}

In general, according to the results presented in Table 2, the lowest average in career anchors was General Management (3.81), with a standard deviation of (1.18); and the highest was Lifestyle (5.10), which presented a standard deviation of (1.28).

Table 2

Averages and standard deviations of career anchors

\begin{tabular}{ccccccccc}
\hline Year & TF & GM & SS & EC & SD & AI & PC & LS \\
\hline $\mathrm{N}$ & 16 & 13 & 16 & 32 & 16 & 22 & 17 & 57 \\
Average & $4.29(0.96)$ & $3.81(1.18)$ & $3.90(1.25)$ & $4.13(1.53)$ & $3.97(1.23)$ & $4.48(1.13)$ & $4.23(1.11)$ & $5.10(1.28)$ \\
\hline
\end{tabular}

Note: Standard deviation indicated in parentheses.

To interpret such result, it is important to retrieve the characteristics of these two anchors, according to Schein's reflections (1990). The concept presented by this author predicts that, for professionals that hold the General Management anchor, the motivation to lead and manage other people is imperative. According to the results presented in Table 2, and in consonance with the theoretical framework, we can suppose that, in general, respondents' anchors do not guide them towards management careers, typical of organizational careers (Sullivan \& Baruch, 2009), even though they are students from a Business Administration course.

On the other hand, the Lifestyle anchor involves choices associated with the way of living, which gives priority to the balance between personal and family needs and professional demands. The career, in this case, must be flexible enough to allow such balance. Coinciding with Generation Y characteristics, this result reflects the fact that this generation tends to prefer more flexible work schemes in order to devote to its personal objectives (Cennamo \& Gardner, 2008).

\subsection{Career anchors and values}

After classifying career anchors as independent variables, general averages and standard deviations can be presented for the respondents' motivational types and values, according to Table 3. The highest average was in the Hedonism motivational type (5.19), a result compatible with the findings of Twenge et al. (2010), which classifies Generation Y professionals as people who seek, primarily, satisfaction of their personal needs and pleasure in their daily work routine. The lowest average was in the Power motivational type (4.10). This result supports what was found when measuring career anchors, where the General Management anchor showed the lowest average among the others. Also worth noting is the fact that the dimension corresponding to the Self-promotion value (4.51) presented the lowest average among the grouping of four value dimensions. In order to understand this result, it is important to remember that, in Schwartz's view (1994), this value is made up of the relationship between the Achievement and Power motivational types, focused on personal interests and not social interests. 
Table 3

General averages and standard deviations

\begin{tabular}{lcc}
\hline Motivational types & Average & $\begin{array}{c}\text { Standard } \\
\text { deviation }\end{array}$ \\
\hline Self-determination & 4.95 & 0.52 \\
Benevolence & 5.10 & 0.56 \\
Conformity & 4.91 & 0.62 \\
Stimulation & 4.44 & 0.83 \\
Hedonism & 5.19 & 0.87 \\
Power & 4.10 & 0.87 \\
Achievement & 4.93 & 0.63 \\
Security & 4.94 & 0.56 \\
Tradition & 4.22 & 0.72 \\
Universal & 4.76 & 0.64 \\
\hline Values & & \\
\hline Openness to change & 4.84 & 0.52 \\
Self-transcendence & 4.94 & 0.54 \\
Self-promotion & 4.51 & 0.67 \\
Conservation & 4.68 & 0.53 \\
\hline
\end{tabular}

Subsequently, through ANOVA, with regard to respondents' career anchor associated with the ten motivational types analyzed, Scheffés post-hoc test found a significant difference $(\mathrm{p}<0.05)$ in the motivational types: Benevolence
$(\mathrm{F}=1.90 ; \mathrm{p}<0.05)$, Stimulation $(\mathrm{F}=2.94 ; \mathrm{p}<0.01)$, Power $(\mathrm{F}=2.35 ; \mathrm{p}<0.05)$ and Achievement $(\mathrm{F}=2.04 ; \mathrm{p}<0.05)$.

People with Autonomy and Independence as main career anchor presented the highest averages on the Stimulation motivational type (4.83). Respondents with the General Management anchor presented the highest averages on the Achievement (5.21) and Power (4.61) motivational types. Those who had the Service and Dedication to one Cause anchor had the highest averages on the Benevolence (5.41) and Universalism (5.07) values. On the other hand, people with the Service and Dedication to one Cause anchor had the lowest averages on the Achievement (4.65) and Power (3.5) motivational types. Furthermore, respondents with the Security and Stability anchor had the lowest averages on the Stimulation (4.00) value.

Proceeding with the analyses, we can observe, in Table 4, correlations among all of respondents' career anchors and motivational types. These correlations identify the pertinence in the results obtained in the analyses of variances previously carried out.

Table 4

Correlations between career anchors and values

\begin{tabular}{ccccccccccc}
\hline & Univ. & Benev. & Achiev. & Power & Hedon. & Stimul. & Self-det. & Secur. & Confor. & Trad. \\
\hline TF & 0.20 & 0.18 & 0.41 & 0.42 & 0.21 & 0.15 & 0.24 & 0.34 & 0.30 & 0.25 \\
GM & -0.21 & 0.16 & $0.58^{* *}$ & $0.56^{* *}$ & 0.26 & 0.32 & 0.43 & 0.26 & 0.14 & 0.36 \\
AI & 0.13 & 0.12 & 0.12 & -0.11 & 0.26 & $0.51^{* *}$ & 0.37 & 0.32 & -0.21 & -0.20 \\
SS & 0.30 & -0.23 & 0.14 & 0.42 & -0.03 & -0.37 & -0.12 & $0.52^{* *}$ & $0.50^{* *}$ & $0.51^{* *}$ \\
EC & -0.31 & -0.24 & $0.64^{* *}$ & 0.50 & 0.33 & $0.55^{* *}$ & 0.45 & 0.11 & -0.23 & 0.26 \\
SD & $0.60^{* *}$ & $0.62^{* *}$ & -0.14 & -0.31 & 0.12 & 0.10 & 0.35 & 0.29 & 0.11 & 0.38 \\
PC & 0.08 & 0.13 & 0.48 & 0.28 & 0.14 & 0.47 & 0.38 & 0.10 & 0.25 & 0.26 \\
LS & $0.50^{* *}$ & 0.38 & -0.34 & -0.20 & 0.21 & -0.10 & 0.12 & $0.40^{*}$ & 0.22 & 0.26 \\
\hline
\end{tabular}

Note. ${ }^{* *} \mathrm{p}<.01$

In the correlations presented on the table above, the significance of $(\mathrm{p}<0.01)$ was considered, with all being moderately positive and correlated. The General Management career anchor had correlation with the Achievement
(0.58) and Power (0.56) motivational types. Security and Stability correlated with Security (0.52), Conformity (0.50) and Tradition (0.51) motivational types. Respondents with the Autonomy and Independence anchor 
had correlation with the Stimulation (0.51) value. Service and Dedication to one Cause was correlated with Universalism (0.60) and Benevolence (0.62), and Lifestyle correlated with Universalism (0.50). Therefore, hypothesis 4 was only partially confirmed in the mentioned cases.

\subsection{The perspective of career concepts}

When the conglomerate analysis was carried out, among respondents, 59\% (112) were grouped in the organizational career model; $41 \%$ (77) in new careers, according to results shown in Table 5.

\section{Table 5}

\section{Conglomerate analysis according to career anchors and values}

\begin{tabular}{|c|c|c|c|c|}
\hline & $\begin{array}{c}\text { Organizational career } \\
\text { (112 respondents) }\end{array}$ & $\begin{array}{c}\text { New careers } \\
\text { (77 respondents) }\end{array}$ & $\mathbf{F}$ & Significance \\
\hline \multicolumn{5}{|l|}{ Career anchors } \\
\hline GM & 4.19 & 3.26 & 32.75 & 0.00 \\
\hline AI & 4.00 & 4.82 & 27.46 & 0.00 \\
\hline SD & 3.90 & 4.70 & 31.03 & 0.00 \\
\hline LS & 4.76 & 5.59 & 21.22 & 0.00 \\
\hline SS & 4.07 & 3.00 & 32.26 & 0.00 \\
\hline $\mathrm{TF}$ & 4.45 & 4.07 & 7.36 & 0.07 \\
\hline $\mathrm{EC}$ & 2.99 & 4.92 & 117.75 & 0.00 \\
\hline PC & 3.83 & 4.51 & 18.36 & 0.00 \\
\hline \multicolumn{5}{|l|}{ Motivational types } \\
\hline Universalism & 4.75 & 4.78 & 0.09 & 0.77 \\
\hline Benevolence & 5.14 & 5.05 & 1.13 & 0.29 \\
\hline Achievement & 5.19 & 4.56 & 56.40 & 0.00 \\
\hline Power & 4.38 & 3.70 & 32.65 & 0.00 \\
\hline Stimulation & 3.94 & 4.78 & 61.01 & 0.00 \\
\hline Security & 5.01 & 4.85 & 3.63 & 0.01 \\
\hline Conformity & 4.94 & 4.88 & 0.31 & 0.57 \\
\hline Tradition & 4.90 & 4.12 & 2.79 & 0.00 \\
\hline Hedonism & 5.36 & 4.95 & 10.53 & 0.00 \\
\hline Self-determination & 5.11 & 4.72 & 29.168 & .000 \\
\hline
\end{tabular}

Note. ${ }^{* *} \mathrm{p}<.01 ;{ }^{*} \mathrm{p}<.05$

To differentiate the groups presented in Table 5, the fact that the General Management anchor (4.19) and the Security and Stability anchor (4.07) had the highest averages in the organizational careers group was considered. As to motivational types, the highest averages considered in this group were as follows: Achievement (5.19); Power (4.38); Security (5.01); Tradition (4.90); Hedonism (5.36) and Self-determination (5.11). Conceptually, it is important to remember that these career types have the organizational structure as a determining factor in the decisions of the individual (Arthur et al., 1999).

At the same time, the Autonomy and Independence (4.82); Lifestyle (5.59); Service and Dedication to one Cause (4.70) and Entrepreneurial Competency (4.92) anchors were the ones with the highest averages in the new careers group, where the Stimulation (4.78) motivational type achieved the highest average in this group. Conceptually, it is worth stressing that in this type of career the individual is the main 
role player, that is, the person manages his/her own development, considering the organizations' flexibility and independence factors (Arthur et al., 1999).

In order, the anchors that mostly differentiated the two groups were Entrepreneurial Creativity $(\mathrm{F}=117.75 ; \mathrm{p}<0.01)$; General Management $(F=32.75 ; \mathrm{p}<0.01)$; Security and Stability $(\mathrm{F}=32.26 ; \mathrm{p}<0.01)$; Service and Dedication to one Cause $(\mathrm{F}=31.03 ; \mathrm{p}<0.01)$; Autonomy and Independence $(\mathrm{F}=27.46 ; \mathrm{p}<0.01)$; Lifestyle $(\mathrm{F}=21.22 ; \mathrm{p}<0.01)$; and $\mathrm{PC}(\mathrm{F}=18.36$; $\mathrm{p}<0.01)$. Results reveal that the Functional Technical Competency did not achieve statistical significance to differentiate career orientations.

In the classification of motivational types, the ones that mostly differentiated the two groups were: Stimulation $(\mathrm{F}=61.01$; $\mathrm{p}<0.01)$; Achievement $\quad(\mathrm{F}=56.40$; $\mathrm{p}<0.01)$; Power $(\mathrm{F}=32.65 ; \mathrm{p}<0.01)$; Selfdetermination $\quad(\mathrm{F}=29.168$; $\mathrm{p}<0.01) ;$ Hedonism $\quad(\mathrm{F}=10.53$; $\mathrm{p}<0.01)$ and Security $(\mathrm{F}=3.63 ; \mathrm{p}<0.01)$. Universalism, Benevolence and Conformity values were not significant $(\mathrm{p}<0.05)$.

Even though some anchors and motivational types did not show significance, most of these factors allowed the division of respondents in two groups. Therefore, Hypotheses 1,2 and 3 were confirmed, since these factors were confirmed in both groups, representing organizational career aspects as well as new career aspects. These factors also served to differentiate both groups in the conglomerate analysis, at a higher or lower level.

In general, the conglomerate analysis enabled the identification of both groups in relation to the respective career anchors and values. Firstly, we found that, in the group of respondents oriented towards organizational careers, the biggest differentiator was the General Management career anchor, possibly due to the valuing of Power and Achievement that, together, in Schwartz's view (1994), were characterized by social esteem and status.
In the new careers group, Stimulation was the motivational type with the highest importance which, in the analysis of variance, also showed to be in line with Autonomy and Independence career anchor professionals. A possible explanation for this incidence is that people in this anchor are resistant to organizational rules that conflict with their values. It is important to remember that, in Schwartz's view (1994), the Stimulation motivational type relates to the search for diverse and stimulating activities.

It is important to highlight that, on the data presented in Tables 2 and 3, only the results on respondents' general perception were considered. As to values, the results of the dimensions described in Table 3, which presented the lowest averages in the Self-promotion dimension, were not considered in the groupings that generated the division of conglomerates described in Table 5. This table shows that organizational careers groups can be considered to be further oriented towards the Self-promotion dimension than the new careers group. This is because respondents within this conglomerate presented the highest averages both in Achievement as well as in Hedonism and Power. In the same way, the General Management anchor, which is lower in Table 2, shows significance in the organizational careers group in Table 5. It is essential to highlight that these possible contradictions show the importance of establishing new methodology analyses for the study of career anchors, since the division of respondents in conglomerates enabled to cover reflections on the understanding of careers by the young adults surveyed.

The conglomerate division analysis, in association with the generations' literature, shall consider studies such as that conducted by Veloso et al. (2012). These authors attest that Generation $\mathrm{Y}$ in Brazil lives a period of questioning their traditional values in relation to careers, established by previous generations. This view would bring the possibility of a limitation of the results in this study; however, the Hedonism motivational type in this group shows a different expectation by previous generations with regard to careers 
in organizations. By associating organizational work to hedonist pleasure and to the sense of self-gratification, these young adults differentiate themselves from the Baby Boom generation that, according to Silva et al. (2015), is more loyal to employers; but also from Generation X, which is skeptical in relation to organizational work.

\subsection{Implications on the theory}

The results of the relationship between anchors and motivational types forming values confirm a conceptual coherence, which suggests that both instruments, when applied on the same audience, enable deeper conceptual analyses regarding career choices.

Although hypothesis 4 - which predicted the relationship between Generation Y anchors and values - was not completely confirmed, the coherence among the correlated results is clear. We can observe that anchors more related to management are correlated with more individualist values, while anchors more related to society and independence are more correlated with social values.

To evaluate the contribution of the respondents' framework in a generational group for Business Administration literature, it is important to stress that different authors (Segers, Inceoglu, Vloeberghs, Bartram, \& Henderickx, 2008; Veloso et al., 2011) have already identified that different groups of employees perceive certain aspects of organizational life in different ways, and that they are impacted in different levels by organizational efforts to manage their careers. Therefore, understanding the professional choices demonstrated by the anchors in their relationship with this generation's values can produce conceptual reflections not only concerning Generation Y, but also with regard to the theories that involve people management.

As to the literature of these generations, the confirmation of a bigger number of respondents in the organizational careers group indicates that, in the Brazilian context, Generation Y differs from the North American classification with regard to its bigger dependency in the management of their careers by the organizations they work for. This result can raise new findings about the particularities of this generation, already pointed out in Brazilian literature (Silva et al., 2015). On the other hand, there are similarities among young professionals in these two countries, according to the study by Twenge et al. (2010), especially in relation to the desire of quickly ascending in the organizational hierarchy, confirmed in this study by the predominance of Power and Achievement motivational types.

As to career management literature, the evidence that organizational careers are predominant in this generation brings the possibility of revalidation of Hall's view (2002) in which the career characterized as progress in a hierarchic structure occupies the popular view on careers. According to the results in this research, this is a reality not only among older professionals, as one would expect, but also among the generation of younger professionals.

\subsubsection{Implications on people management}

At this stage, it is important to rescue Pereira's study (2016) which found, among university teachers predominantly in the 51 to 60 age group, a higher incidence of the Service and Dedication to one Cause anchor and the Universalism motivational type. Yet in the group presented in this study, with an age group compatible with Generation Y, the predominant anchor, Lifestyle, is followed by the Hedonism motivational type.

The relevance in adopting Generation Y parameters to relate career anchors to values of respondents lies in the fact that, in Brazil, there is evidence that this generation started in 1986 (Silva et al., 2015). This means that these professionals, currently in their 30s, tend to broaden their participation in companies and to ascend to management roles. The results in this study also enable the assumption that, for companies, the identification of occupational groups with inclinations towards common anchors and values may consist in an important tool for setting tasks and attributions in line with their employees' professional inclinations. For educational institutions that offer Business Administration courses, it is relevant to reflect on a syllabus focused on the development of company managers, which 
may not be in line with the more social view of work in certain groups, whose values distance themselves from those linked to organizational management roles.

\subsubsection{Implications on career management}

In the division of conglomerates carried out in this study, it can be noted that the characteristics of the Lifestyle anchor were predominant in the differentiation of the smaller group of respondents (the new careers group), composed of 77 respondents. The General Management anchor, with the lowest incidence in this study, was predominant in the characterization of the bigger conglomerate (the organizational careers group), which had 114 respondents. Considering that previous research, with a similar sample to this work, also demonstrated the predominance of the Lifestyle career anchor (Gomes et al., 2013; Trevisan et al., 2015; Veloso et al., 2014), the need for a deeper analysis of the topics proposed in this article is highlighted.

The confirmation of hypotheses 1,2 and 3 in this research indicates the potential of the instruments used in this work to differentiate groups oriented by different career concepts. This fact reinforces the understanding that the analysis of anchors and values can encourage new studies in the career management field. Carrying out new analyses is vital for a better understanding about the predisposition of people to adopt new career formats. In order to broaden and develop this field of study, it is equally important to employ "new uses" of traditional instruments, such as the anchors, that allow building relationships between old and new career concepts.

\section{Final considerations}

Considering the findings in this study, it is possible to affirm that, in order to suit Generation $\mathrm{Y}$, career management models adopted by companies must consider, in their structure, both organizational careers and new careers. Clarke (2013) suggests, for example, the new organizational career, which combines a long-term job with fulfilling work, constant changes and great possibilities of internal moves. Therefore, people management in organizations would have the role of understanding that sets of values are compatible with different groups of professionals.

With regard to careers, Generation Y subjects sampled in this study identified themselves predominantly with the Lifestyle anchor and the Hedonism motivational type, associated with self-gratification. The fact that these young adults show generational characteristics that require people management to provide a work structure that stimulates, at the same time, learning, pleasure and self-achievement, as well as the reconciliation between work and personal life, must be considered.

On the other hand, the lowest incidence of the General Management anchor and the Power motivational type may not mean lack of interest for the work in organizations. In this study, the use of these factors in the formation of the "organizational careers" group indicates that the interest remains, but in a different manner, probably including the constant search for satisfaction in the work routine and in personal life. Such hybridity indicates the need for a better understanding of this phenomenon through new researches.

As a limitation, this research did not enable conclusions in relation to other aspects of Generation Y's involvement with their professional lives such as, for example, with leadership procedures. As already indicated by Schein (1990), the momentary evaluation of anchors can lead to interpretation errors. In the same way, the isolated evaluation of motivational types that form values require the building of relationships among them for a better understanding (Schwartz, 1994).

Generally, the results found in this study indicate the relevance of the use of two forms of analysis on Generation Y's career choice orientations: anchors and values, which must be explored in greater depth in future studies. Researches with larger and more significant samples are needed to assert the trends identified in this study, including relating them to new career concepts. 


\section{References}

Arthur, M. B., Claman, P. H., \& DeFillippi, R. (1995). Intelligent enterprise, intelligent careers. Academy of Management Executive, 9(4), 7-20.

Arthur, M. B., Inkson, K., \& Pringle, J. K. (1999). The new careers: Individual action and economic change. London: Sage.

Arthur, M. B., \& Rousseau, D. (1996). The boundaryless career: A new employment principle for a new organizational era. New York: University Press.

Bendassolli, P. F. (2009). Recomposição da relação sujeito-trabalho nos modelos emergentes de carreira. Revista de Administração de Empresas$R A E$, 49(4), 387-400.

Bido, D. S., Souza, C. A., Silva, D., Godoy, A. S., \& Torres, R. T. (2010). Qualidade do relato dos procedimentos metodológicos em periódicos nacionais na área de administração de empresas: O caso da modelagem em equaçóes estruturais nos periódicos nacionais entre 2001 e 2010. Organizaçóes e Sociedade, 19(60), 125-144.

Briscoe, J. P., \& Finkelstein, L. M. (2009). The "new career" and organizational commitment - do boundaryless and protean attitudes make a difference? Career Development International, 14(3), 242-260.

Briscoe, J. P., Hall, D. T., \& DeMuth, R. L. F. (2006). Protean and boundaryless careers: An empirical exploration. Journal of Vocational Behavior, 69(1), 30-47.

Caldas, M. P. (2006). Conceptualizing Brazilian multiple and fluid cultural profiles. Management Research: The Journal of the Iberoamerican Academy of Management, 4 (3), 169-180.

Cennamo, L., \& Gardner, D. (2008). Generational differences in work values, outcomes and personorganisation values fit. Journal of Managerial Psychology, 23(8), 891-906.

Clarke, M. (2013). The organizational career: Not dead but in need of redefinition. The International
Journal of Human Resource Management, 24(4), 684-703.

Costanza D. P., Badger J. M., Fraser R. L, Severt J. B., \& Gade P. A. (2012). Generational Differences in Work-Related Attitudes: A Meta-analysis. Journal of Business and Psychology, 27(4), 375-394.

D’Amato, A., \& Herzfeldt, R. (2008). Learning orientation, organizational commitment and talent retention across generations: A study of European managers. Journal of Managerial Psychology, 23(8), 929-953.

Dutra, J. S. (2002). A gestão de carreira. In M. T. L. Fleury (Coord.), As pessoas na organização (pp. 99-114). São Paulo: Ed. Gente.

Dutra, J. S. (Org.). (2010). Gestão de carreiras na empresa contemporânea. Sáo Paulo: Atlas.

Elder, G. H. (1998). The life course as developmental theory. Child Development, 69(1), 1-12.

Gil, A. C. (1999). Métodos e técnicas de pesquisa social (5a ed). São Paulo: Atlas.

Gomes, D. F. N., Moraes, K. S., Barbosa, R. P., \& Trevisan, L. N. T. (2013). Âncoras de carreiras: revisão do conceito de mobilidade a partir de estudo com egressos do curso de Administraçáo em dois momentos - 2007 e 2010. ReCaPe Revista de Carreiras \& Pessoas, 3(1), 50-62.

Hair, J. R., Black, W. C, Babin, B. J., Anderson, R. E., \& Tatham, R. L. (2009). Análise multivariada de dados (6a ed.). Porto Alegre: Bookman.

Hall, D. T. (2002). Careers in and out of organizations. London: Sage.

Hofstede, G. (1997). Culturas e organizaçôes: Compreender a nossa programação mental. Lisboa: Silabo.

Howe, N., \& Strauss, W. (2007). The next 20 years: How customer and workforce attitudes will evolve. Harvard Business Review, 85(7-8), 41-52.

Ibarra, H. (2009). Identidade de carreira: A experiência é a chave para reinventá-la. São Paulo: Ed. Gente. 
Kilimnik, Z. M., Sant'anna, A. S., Oliveira, L. C. V., \& Barros, D. T. (2008). Seriam as âncoras de carreiras estáveis ou mutantes? Um estudo com profissionais de Administração em transição de carreira. Revista Brasileira de Orientação Profissional-ABOP, 9(1), 43-60.

Lyons, S., \& Kuron, L. (2014). Generational differences in the workplace: A review of the evidence and directions for future research. Journal of Organizational Behavior, 35(S1), 139-157.

Moura, A. M., Comini, G., \& Teodósio, A. S. S. (2015). The international growth of a social business: A case study. Revista de Administração de Empresas, 55(4), 444-460.

Pereira, L. M. (2016). Transição de carreira para a docência universitária: Um estudo sobre a influência dos valores pessoais e âncoras de carreira (Masters' dissertation). Programa de Pós-graduação em Administração, Pontifícia Universidade Católica de São Paulo, São Paulo, Brasil.

Reis, G. G., Antonio, F. A. A., Laizo, A., \& Marinho, B. L. (2010). Os valores dos administradores de empresas mudam ao longo da carreira? Relaçóes entre prioridades axiológicas e tempo de formado. Revista de Administração do Mackenzie-RAM, 11(5), 32-54.

Robbins, S. P., Judge, T. A., \& Sobral, F. (2010). Comportamento organizacional (14a ed.). São Paulo: Pearson Prentice Hall.

Rokeach, M. (1979). Understanding human values: Individual and social. London: The Free Press.

Rosolen, T. (2014). Negócios sociais e valores pessoais: Um estudo quantitativo com estudantes de administração (Masters' dissertation). Programa de Pós-graduação em Administração, Universidade de São Paulo, São Paulo, Brasil.

Santos, N. M. B. F., \& Abrahim, G. S. (2008). A influência dos valores pessoais na determinação das âncoras de carreira. Anais do Encontro da ANPAD, Rio de Janeiro, RJ, Brasil, 32. Recuperado de http://www.anpad.org.br/admin/ pdf/GPR-A871.pdf
Schein, E. H. (1990). Career Anchors: Discovering Your Real Values. San Diego, CA: Pfeiffer \& Company.

Schwartz, S. H. (1994). Are there universal aspects in the structure and contents of human values? Journal of Social Issues, 50(4), 19-45.

Schwartz, S. H. (2005). Validade e aplicabilidade da teoria de valores. In A. Tamayo \& J. B. Porto (Orgs.), Valores e comportamento nas organizaçôes (pp. 56-95). Petrópolis, RJ: Vozes.

Segers, J., Inceoglu, I., Vloeberghs, D., Bartram, D., \& Henderickx, E. (2008). Protean and boundaryless careers: A study on potential motivators. Journal of Vocational Behavior, 37(2), 212-230.

Silva, R. C., Dias, C. A. F, Krakauer, P. V. C., Silva, M. T. G., \& Marinho, B. L. (2012). Carreiras: novas ou tradicionais? Um estudo com profissionais brasileiros. ReCaPe-Revista de Carreiras \& Pessoas, 2(1), 19-39.

Silva, R. C., Dutra, J. S., Veloso, E. F. R., Fischer, A. L., \& Trevisan, L. N. (2015). Generational perceptions and their influences on organizational commitment. Management Research: The Journal of the Iberoamerican Academy of Management, 13(1), 5-30.

Silva, R. C., Trevisan, L. N., Veloso, E. F. R., \& Dutra, J. S. (2014). Âncoras de carreiras e valores laborais: Implicaçôes para a gestão de carreira das organizaçōes. Anais do Encontro da Anpad, Rio de Janeiro, RJ, Brasil, 38.

Smola, K. W., \& Sutton, C. D. (2002). Generational differences: Revisiting generational work values for the new Millennium. Journal of Organizational Behavior, 23(4), 363-382.

Sullivan, S. E., \& Baruch, Y. (2009). Advances in career theory and research: A critical review and agenda for future exploration. Journal of Management, 35(6), 1542-1571.

Trevisan, L. N. T., Veloso, E. F. R., Silva, R. C., \& Dutra, J. S. (2015). O auxílio das âncoras de 
carreira na análise das percepçôes sobre estresse e tecnologia no ambiente de trabalho. Anais do Encontro de Gestão de Pessoas e Relaçóes de Trabalho - EnGPR, Salvador, BA, Brasil, 5.

Twenge, J. M., Campbell, S. M., Hoffman, B. J., \& Lance, C. E. (2010). Generational differences in work values: Leisure and extrinsic values increasing, social and intrinsic values decreasing. Journal of Management, 36(5), 1117-1142.

Veloso, E. F. R. (2012a). Carreiras sem fronteiras e transição profissional no Brasil: Desafios e oportunidades para pessoas e organizaçóes. São Paulo: Atlas.

Veloso, E. F. R. (2012b). É possível negar a existência da geraçáo Y no Brasil? Revista Organizaçôes \& Sociedade, 19(63), 745-747.

Veloso, E. F. R., Dutra, J. S., Fischer, A. L., Pimentel, J. E. A., Silva. R. C., \& Amorim, W. A. C. (2011). Gestão de carreiras e crescimento profissional. Revista Brasileira de Orientação Profissional-ABOP, 12(1), 61-72.
Veloso, E. F. R., \& Dutra, J. S. (2010). Evolução do conceito de carreira e sua aplicaçáo para a organização e para as pessoas. In J. S. Dutra (Org.), Gestão de carreiras na empresa contemporânea (pp. 3-39). São Paulo: Atlas.

Veloso, E. F. R., Silva, R. C., \& Dutra, J. S. (2012). Diferentes geraçôes e percepçôes sobre carreiras inteligentes e crescimento profissional nas organizações. Revista Brasileira de Orientação Profissional, 13(2), 197-207.

Veloso, E. F. R., Silva, R. C., Trevisan, L. N. T., Gomes, D. F. N., \& Dutra, J. S. (2014). Momento social, valores e expectativa: Como as mudanças econômicas influenciam a visão dos jovens sobre o trabalho? Revista Organizaçóes em Contexto, 10(19), 279-305.

Westerman, J. W., \& Yamamura, J. H. (2007). Generational preferences for work environment fit: Effects on employee outcomes. Career Development International, 12(2), 150-161.

\section{About the Authors:}

1. Rodrigo Cunha da Silva, Phd in Business Administration from the Faculty of Economics, Business Administration and Accounting - FEA/USP. E-mail: rdgcdasilva@gmail.com

2. Leonardo Nelmi Trevisan, Phd in Political Science from the University of São Paulo. E-mail: Intrevisan@pucsp.br 3. Elza Fátima Rosa Veloso, Phd in Business Administration from the Faculty of Economics, Business Administration and Accounting - FEA/USP. E-mail: elzafr@uol.com.br

4. Joel Souza Dutra, Phd in Business Administration from the Faculty of Economics, Business Administration and Accounting - FEA/USP. E-mail: jdutra@usp.br

\section{Contribution of each Author:}

\begin{tabular}{|c|c|c|c|c|}
\hline Contribution & $\begin{array}{c}\text { Rodrigo } \\
\text { Silva }\end{array}$ & $\begin{array}{l}\text { Leonardo } \\
\text { Trevisan }\end{array}$ & $\begin{array}{c}\text { Elza } \\
\text { Veloso }\end{array}$ & $\begin{array}{l}\text { Joel } \\
\text { Dutra }\end{array}$ \\
\hline 1. Definition of research problem & $\sqrt{ }$ & $\sqrt{ }$ & $\sqrt{ }$ & $\sqrt{ }$ \\
\hline $\begin{array}{l}\text {. Development of hypotheses or research questions (empirical } \\
\text { studies) }\end{array}$ & $\sqrt{ }$ & $\sqrt{ }$ & $\sqrt{ }$ & \\
\hline 3. Development of theoretical propositions ( theoretical Work ) & $\sqrt{ }$ & $\sqrt{ }$ & $\sqrt{ }$ & $\sqrt{ }$ \\
\hline 4. Theoretical foundation/ Literature review & $\sqrt{ }$ & $\sqrt{ }$ & $\sqrt{ }$ & $\sqrt{ }$ \\
\hline 5. Definition of methodological procedures & $\sqrt{ }$ & $\sqrt{ }$ & $\sqrt{ }$ & \\
\hline 6. Data collection & & $\sqrt{ }$ & & \\
\hline 7. Statistical analysis & $\sqrt{ }$ & & & \\
\hline 8. Analysis and interpretation of data & $\sqrt{ }$ & $\sqrt{ }$ & $\sqrt{ }$ & $\sqrt{ }$ \\
\hline 9. Critical revision of the manuscript & $\sqrt{ }$ & $\sqrt{ }$ & $\sqrt{ }$ & $\sqrt{ }$ \\
\hline 10. Manuscript Writing & $\sqrt{ }$ & $\sqrt{ }$ & $\sqrt{ }$ & \\
\hline 11. Other (please specify which) & & & & \\
\hline
\end{tabular}

